\title{
HERBAL EXTRACTS FOR ENSURING PORK MEAT QUALITY DURING COLD STORAGE
}

\author{
Ilze Grāmatiṇa\#", Sanita Sazonova, Zanda Krūma, Lìga Skudra, and Lìga Prieciṇa \\ Faculty of Food Technology, Latvia University of Agriculture, 22 Rīgas Str., Jelgava, LV-3004, LATVIA \\ \# Corresponding author, ilzegramatina@inbox.Iv
}

Communicated by Inga Ciproviča

\begin{abstract}
Oxidation and microbial spoilage have a negative effect on the quality of meat and meat products, causing changes in their sensory and nutritional properties. Herbs contain biologically active compounds, like phenols with antioxidative and antimicrobial properties. Phenols can be used as substitutes for commercial antioxidants to prevent lipid oxidation, thus maintaining the colour and flavour of the product. The aim of the study was to investigate the the potential use of herbal extracts in ethanol/water application for the maintenance of pork meat quality during storage. Four herbs growing in Latvia - nettle (Urtica dioica L.), lovage (Levisticum officinale L.), oregano (Origanum vulgare), and horseradish (Armoracia rusticana L.) were chosen for the study. An optimal ethanol concentration for the extraction of the phenolic compounds was obtained with ethanol $50 \% /$ water $50 \%$ concentration $(\mathrm{V} / \mathrm{V})$. Prepared herbal extracts were added to chilled pork to determine the quality of the pork during storage. Changes in meat quality and its sensory properties for chilled pork without extracts appeared on day 18 of storage. Negative changes in sensory properties of meat samples with nettle extract were observed on day 22 of storage, and with lovage, oregano, and horseradish extracts on day 32. Statistically significant differences $(p \leq 0.05)$ were observed for microbiological indices between pork samples with herbal extracts and the control sample.
\end{abstract}

Key words: oregano extract, lovage extract, nettle extract, phenols, pork.

\section{INTRODUCTION}

Meat is the muscle tissue of slaughter animals. It is composed of water, proteins, lipids, minerals, and a small proportion of carbohydrates. Meat and meat products are susceptible to quality deterioration due to their rich nutritional composition (Shah et al., 2014). The main changes of quality are due to oxidation and microbial spoilage of the meat samples, whereby meat products become unacceptable from a sensory (colour, texture and flavour), nutritional, microbiological or safety perspective (Kanner, 1994; Zhang et al., 2010; Devatkal et al., 2014). Lipid oxidation is a complex process and depends on the chemical composition of meat, oxygen access, light, and storage temperature (Karakaya et al., 2011). It is possible to reduce or inhibit lipid oxidation by the use of antioxidants in meat and meat product production. The use of natural antimicrobials certified as generally recognised as safe (GRAS) has been widely accepted by consumers. Natural additives are used to extend shelf life and overall quality through the inhibition of oxidative rancidity and microbial spoilage (Shah et al., 2014). The application of synthetic additives is limited by food legislation and consumers are concerned about the safety of synthetic food additives; therefore, the demand for the use of natural ingredients in foodstuffs has increased lately (Devatkal et al., 2014).

Herbs, spices, aromatic plants, berries, and their extracts have been studied as potential natural antioxidants containing substrates in meat and meat products (McCarthy et al., 2001; Søltoft-Jensen and Hansen, 2005; Hayouni et al., 2008; Viskelis et al., 2009; Karakaya et al., 2011). Compounds from herbs and spices contain many phytochemicals, which are potential sources of natural antioxidants including phenolic diterpenes, flavonoids, tannins and phenolic acids (Dawidowicz et al., 2006). These compounds have antioxidant, anti-inflammatory and anticarcinogenic activities (Stratil et al., 2007; Miguel, 2011). In food systems, they can improve flavour, retard lipid oxidation-induced food deterioration, and inhibit the growth of microorganisms (Tanabe, 2002). Some herbs and spices have been characterised by a noticeable antimicrobial activity mainly due to their phenolic compounds (Zhang et al., 2010). However, there is a lack of knowledge about the mechanisms, toxicological as well as the sensorial effects of naturally derived antimicrobials in food (Hygreeva et al., 2014). However, it is possible to delay or inhibit the growth of pathogenic microorganisms in foods (Marino et al., 
2001). Herbal application can be combined with vacuum packaging to maintain the quality of meat products and improve their shelf-life. Improvements in the shelf-life of meat and meat products can have an important economic impact on the reduction of losses attributed to spoilage. (Tang et al., 2001).

For centuries, people have had the knowledge of using local herbs or spices in food production. Some plants have been forgotten but now interest of scientists and consumers in these plants has resumed. Each herb differs by its unique flavour and biochemical composition. Nevertheless, they have common properties, such as high amounts of vitamins and minerals. All these substances are significant for human physiological processes (Milda, 2015). Nowadays consumers have a growing interest in functional foods, and the usage of plants has increased (Kruma and Straumite, 2012). The use of natural preservatives can eliminate the necessity for synthetic additives as well as increase the nutritional value of foodstuffs. Compounds from herbs and spices contain many phytochemicals having a potential of strong antioxidant, antimicrobial and antifungal activity in food. These properties of herbs and spice extracts are due to the presence of many bioactive components, including flavanoids, terpenoids, vitamins, minerals, carotenoids and phytoestrogens (Hygreeva et al., 2014).

The aim of the study was to investigate the potential use of herbal extracts in ethanol/water application for the maintenance of pork meat quality during storage.

\section{MATERIALS AND METHODS}

Sampling and treatment of samples. For the experiment four herbs which grow in Latvia - nettle (Urtica dioica L.), lovage (Levisticum officinale L.), oregano (Origanum vulgare), and horseradish (Armoracia rusticana L.) were chosen. Chilled pork obtained from Musculus longissimus lumborum (Poland) were purchased from a supermarket (unpackaged; stored in a chilled condition at temperature 3 $\pm 1{ }^{\circ} \mathrm{C}$; maximum expiration time $24 \mathrm{~h}$ ). No breed, age, sex or premortal handling was recorded.

Preparation of herbal extracts. Plant extracts were prepared from the plant materials by using different solvents and extraction methods. For the current investigation herbal extracts were prepared from dry herbal material (nettle, lovage, oregano, horseradish) treated in different ethanol/water proportions. For the preparation of extracts the leaves and stems of fresh herbs were chopped and dried in a convection dryer Memmert UF 55 (Memmert, Germany) at +45 $\pm 1{ }^{\circ} \mathrm{C}$ till $6 \%$ moisture was reached and maintained. Dried herbs were ground into powder and added to the ethanol/ water solutions in the following concentrations: 1) ethanol $0 \% /$ water $100 \%$; 2) ethanol $25 \% /$ water $75 \%$; 3) ethanol $50 \% /$ water $50 \%$; 4) ethanol $75 \% /$ water $25 \%$; 5) ethanol $100 \% /$ water $0 \%$.

The proportion of herb powder and ethanol/water solution was $1: 10$. The obtained ground herbs were stirred with etha- nol for one hour at $18 \pm 2{ }^{\circ} \mathrm{C}$ (Dai and Mumper, 2010), then filtered and analysed. Herbal extracts were made in triplicate from each type of herb used.

Determination of total phenolic concentration in herbal extracts. For $1 \mathrm{~mL}$ of herbal extract Folin-Ciocalteu reagent was added, stirred, then $10 \mathrm{~mL}$ of $5 \% \mathrm{Na}_{2} \mathrm{CO}_{3}$ solution was added and stirred again. The absorbance of the prepared solutions was determined by a Jenway 630 spectrometer (Jenway, UK) at $765 \mathrm{~nm}$. The standard curve was obtained by taking the gallic acid as standard and total phenolic concentration was expressed in mg GAE $100 \mathrm{ml}^{-1}$ (Chan et al., 2009).

Preparation of pork soaked in herbal extracts. Before the experiments both physical and microbiological parameters of chilled pork were analysed. The chilled pork was finely cut in $3 \mathrm{~mm}$ thick slices. The sliced pork samples with different herbal extracts were kept in the refrigerator for $24 \mathrm{~h}$ at $4 \pm 2{ }^{\circ} \mathrm{C}$. Maturation of pork meat was necessary for better penetration of the phenolic compound from the surface to the deeper layers of pork. After that pork samples were packed in vacuum bags made from polymer film (PA/PE, density $65 \pm 5 \mu \mathrm{m}$ ) into $200 \mathrm{~g}$ portions, and stored in the refrigerator at $+4 \pm 2{ }^{\circ} \mathrm{C}$. The samples were analysed on day 0 and after $4,11,18,22$, and 32 days of storage. A pork sample without herbal extracts was used as a control to compare the changes of quality parameters during the storage.

Sensory evalution of pork freshness. Before the determination of physical and microbiological parameters of pork, the samples underwent testing of sensory parameters such as the appearance, aroma, colour, and texture fit requirements of fresh meat. When meat spoils, its texture, colour, odour, and taste change. Apart from these changes, toxic substances accumulate in it as well. The surface moisture of meat was determined by touching it with a finger or touching the surface of fresh meat incision with white filter paper. The consistency was measured by pressing the meat with a finger and observing the time required to equilibrate the pressed pit. Odour was determined by analysing meat samples (Januškevičienè et al., 2012). Sensory evaluation of the meat sample was carried out by a specially trained expert.

Determination of $\mathbf{p H}$. The $\mathrm{pH}$ value was measured with a Jenway $3520 \mathrm{pH}$ Meter (Jenway, UK). Calibration of the $\mathrm{pH}$-meter was done with $\mathrm{pH}$ standard solutions of 4.01 and 7.00. The procedure was carried out according to LVS ISO 2917:2004 method. The $\mathrm{pH}$ value for marinated pork meat samples was measured in five repetitions.

Determination of water activity. A 6 g minced meat sample was put in a cup, placed in a LabSwift-aw unit (Novasina, Switzerland), and water activity was determined in triplicate for each sample (measurement range -0.11 to $0.90 \mathrm{a}_{\mathrm{w}}$, with an accuracy of $+/-0.01 \mathrm{a}_{\mathrm{w}}$ ).

Texture analysis. Tenderness of pork meat samples was determined using a TA-XT plus Texture Analyser (Stable 
Micro Systems, AK). A Warner-Bratzler blade set with knife and platform with a gap was used. The sample was placed on the centre of the apparatus and the cutting force (N) was detected. This cutting force represents tenderness (Rosenthal, 1999). Ten repetitions for each sample were performed and the results are presented as an average of those measurements.

Microbiological analysis. Sample preparation for microbiological testing was performed in accordance with the standard method LVS EN ISO 6887-2:2004 "Microbiology of Food and Animal Feeding Stuffs: Preparation of Test Samples, Initial Suspension and Decimal Dilutions for Microbiological Examination. Part 2: Specific Rules for the Preparation of Meat and meat products". Total plate count (TPC) was determined according to the standard LVS EN ISO 4833-1:2014 "Microbiology of the Food Chain: Horizontal Method for the Enumeration of Microorganisms. Part 1: Colony Count at $30{ }^{\circ} \mathrm{C}$ by the Pour Plate Technique (ISO 4833-1:2013)" using Nutrient (NA) agar (Ref. No 01-140), and incubation at $30{ }^{\circ} \mathrm{C}$ for $72 \mathrm{~h}$. Enterobacteriaceae CFU were determined under the standard LVS ISO 21528--2:2004 "Microbiology of food and animal feeding stuffs: Horizontal methods for the detection and enumeration of Enterobacteriaceae. Part 2: Colony-count method" using Violet Red Bile Dextrose (VRBD) agar (Ref. No 01-295) and incubation at $37{ }^{\circ} \mathrm{C}$ for $24 \mathrm{~h}$. Lactic acid bacteria count was determined according to the standard method ISO 9332:2003 "Microbiology of food and animal feeding stuffs: Horizontal methods for the enumeration of mesophilic lactic acid bacteri: Colony-count technique at 30 ${ }^{\circ} \mathrm{C}$ " using MRS agar (Ref. No 01-135) and incubating at 37 ${ }^{\circ} \mathrm{C}$ for $72 \mathrm{~h}$. After incubation, the CFU were counted using a colony counter Acolyte (Synbiosis, UK). Counted CFU were transformed to logarithmic $(\log 10)$ values.

Statistical analysis. Analysis of variance (ANOVA) and the Tukey test were used to determine significant differences among samples. Correlation and regression analyses were performed by determining relationship between tested variables, using Microsoft Excel 2014. Confidence level was 95\% ( $\alpha=0.05)$ (Arhipova and Balina, 2006).

\section{RESULTS}

Determination of phenolic concentration in herbal extracts. In the first part of this study the total phenolic concentration of nettle, lovage, oregano, and horseradish herbal extracts was determined. (Fig. 1). The highest total phenolic concentration for all the studied herbal extracts was obtained in samples with ethanol 50\% / water 50\% solution. The herbal extracts made with pure water and $100 \%$ ethanol showed the lowest total phenolic concentration: for nettle water extract - $45.71 \mathrm{mg} \cdot 100 \mathrm{~g}^{-1}$; for oregano $100 \%$ ethanol extract - $690.99 \mathrm{mg} \cdot 100 \mathrm{~g}^{-1}$; for lovage $100 \%$ ethanol extract $-193.8 \mathrm{mg} \cdot 100 \mathrm{~g}^{-1}$; for horseradish $100 \%$ ethanol extract $-1585.79 \mathrm{mg} \cdot 100 \mathrm{~g}^{-1}$. The highest total phenolic concentration was obtained for oregano and horseradish ex-

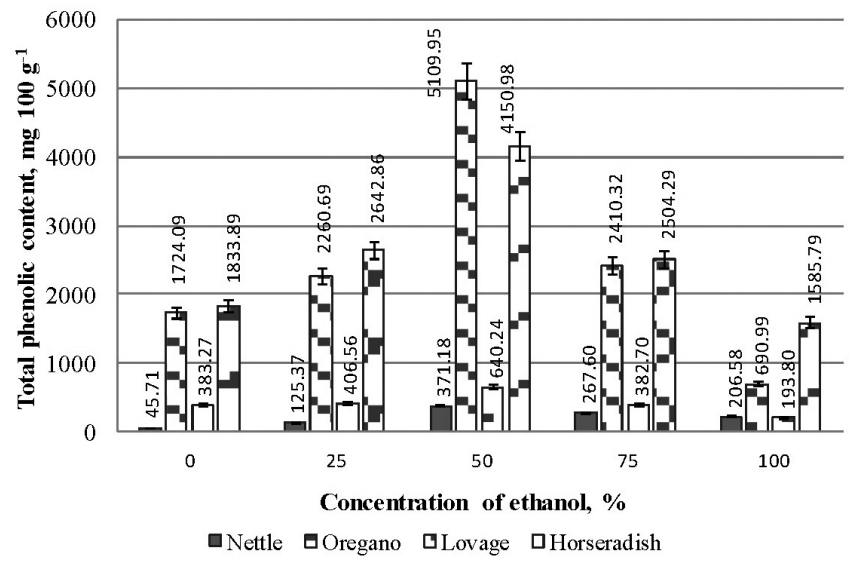

Fig. 1. Total phenolic concentration in herbal extracts.

tract $-5109.95 \mathrm{mg} \cdot 100 \mathrm{~g}^{-1}$ and $4150.98 \mathrm{mg} \cdot 100 \mathrm{~g}^{-1}$ using ethanol $50 \% /$ water $50 \%$ solution.

Evaluation of meat parameters. For the next step of the study the application of herbal extract with ethanol/water concentration $50 \% / 50 \%(\mathrm{v} / \mathrm{v})$ for tested for potential use for extending the shelf life of pork.

The sensory parameters of the samples were analysed on day 0 and after $4,11,18,22$, and 32 days of storage. After testing the sensory parameters, the physical and microbiological parameters of pork samples were analysed. During storage, the freshness of meat samples change as proteins and fats start to break down. Cathepsins and peptidases cause breakage of peptide bonds and lipase fat hydrolysis proceeds. The morphological structure of muscle tissue also changes: meat juice secretes, the surface colour turns brown and unpleasant sour taste develops. Such meat is unfit for human consumption (Januškevičienè et al., 2012). For the control sample the first unpleasant changes in sensory parameters were detected on day 18 of storage, but for the meat samples with nettle extract these changes were observed on day 22. For the meat samples with lovage, oregano and horseradish extracts, negative changes of sensory properties were observed on day 32 of storage.

Changes of $\mathrm{pH}$ (Table 1) may promote the growth of microorganisms and lead to meat deterioration. The results showed a significant difference $(p<0.05)$ between the control sample and pork samples with herbal extracts. At the beginning of the experiments $\mathrm{pH}$ of the chilled pork was $6.17 \pm 0.02$, as in fresh meat. During storage in vacuum packages the $\mathrm{pH}$ of all meat samples significantly $(p<0.05)$ decreased. On day 18, when the negative sensory properties in the control sample were estimated, the $\mathrm{pH}$ was $5.69 \pm$ 0.15 . A decrease in the $\mathrm{pH}$ of pork samples with neetle extract $(\mathrm{pH} 5.75 \pm 0.07)$ was reached on day 22 , and on day 32 for the pork with lovage, oregano and horseradish extracts the $\mathrm{pH}$ was $5.65 \pm 0.11,5.52 \pm 0.11$, and $5.41 \pm 0.14$, respectively.

Water activity (Fig. 2) differences between pork meat samples during storage were significant $(p<0.05)$. The water activity of the control sample on the first day of storage was 
PH DYNAMICS OF CONTROL AND PORK SAMPLES WITH HERBAL EXTRACTS DURING STORAGE

\begin{tabular}{|c|c|c|c|c|c|c|}
\hline \multirow[t]{2}{*}{ Samples } & \multicolumn{6}{|c|}{ Storage days } \\
\hline & 0 & 4 & 11 & 18 & 22 & 32 \\
\hline Control sample & $6.17 \pm 0.02$ & $6.35 \pm 0.11$ & $5.76 \pm 0.12$ & $5.69 \pm 0.15$ & - & - \\
\hline Pork sample with horseradish extract & - & $5.86 \pm 0.09$ & $5.77 \pm 0.12$ & $5.64 \pm 0.12$ & $5.6 \pm 0.10$ & $5.52 \pm 0.11$ \\
\hline Pork sample with lovage extract & - & $5.83 \pm 0.10$ & $5.72 \pm 0.09$ & $5.69 \pm 0.07$ & $5.67 \pm 010$ & $5.65 \pm 0.11$ \\
\hline Pork sample with nettle extract & - & $6.14 \pm 0.11$ & $6.08 \pm 0.07$ & $5.8 \pm 0.09$ & $5.75 \pm 0.07$ & - \\
\hline
\end{tabular}

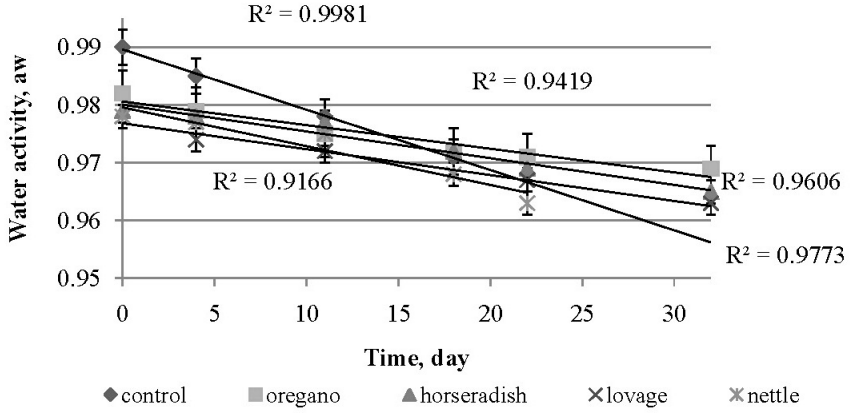

Fig. 2. Water activity dynamics of control and pork samples with herbal extracts during storage.

$0.990 \pm 0.04$, which decreased by day 18 to $0.971 \pm 0.03$. On day 22, the water activity for the pork samples with nettle extract was $0.963 \pm 0.01$ and on day 32 it was $0.969 \pm$ 0.02 for the samples with oregano extracts, $0.965 \pm 0.03$ for the samples with horseradish extract, and $0.963 \pm 0.05$ for the samples with lovage extract applied.

The tenderness of chilled pork was $16.01 \pm 3.63$ N. During storage (Fig. 3) the tenderness of the control sample decreased, whereas for the meat with different herbal extracts it increased (Fig. 3). The tenderness differed significantly $(p<0.05)$ between all meat samples. On day 18 the tenderness for the control sample decreased to $9.21 \pm 0.52 \mathrm{~N}$. The tenderness for the meat samples with nettle extract increased to $21.58 \pm 0.30 \mathrm{~N}$ on day 22 . For the pork meat samples with horseradish, oregano, and lovage extracts the tenderness during storage time for 32 days increased to $27.66 \pm 0.22 \mathrm{~N}, 22.9 \pm 0.38 \mathrm{~N}$, and $20.23 \pm 0.31 \mathrm{~N}$, respectively.

Microbiological criteria. Meat quality depends on the state of the health of animals before slaughter, technical performance of slaughtering, the observance of hygienic requirements in the slaughterhouse, and transporting conditions of carcasses. The compliance with technological and hygienic requirements permits derogations, since both the carcass and cut meat in the sales places are subject to an increased contamination with microorganisms, which are dangerous to human health (Januškevičienè et al., 2012). The laws of the Republic of Latvia and Cabinet of Ministers' regulations, as well as Regulation (EC) No. 2073/2005 on the microbiological criteria for foodstuffs (Anonymous, 2005) do not regulate the number of units of MAFAM colony forming units (CFU) in chilled meat. Therefore, for this study,

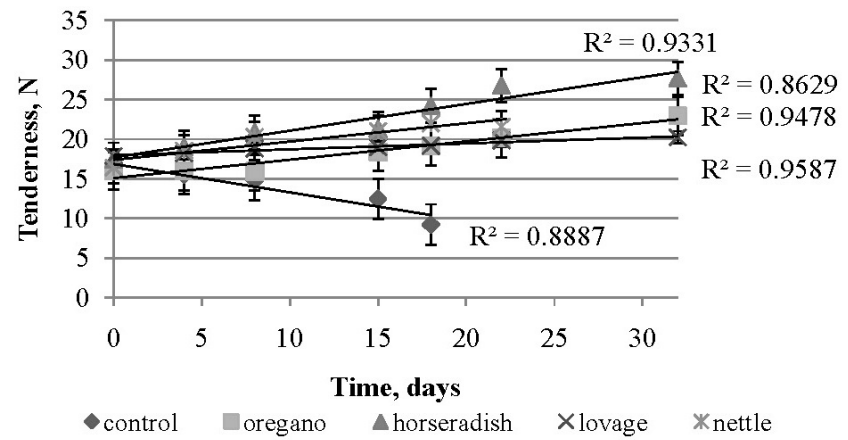

Fig. 3. Tenderness dynamics of control and pork samples with herbal extracts during storage.

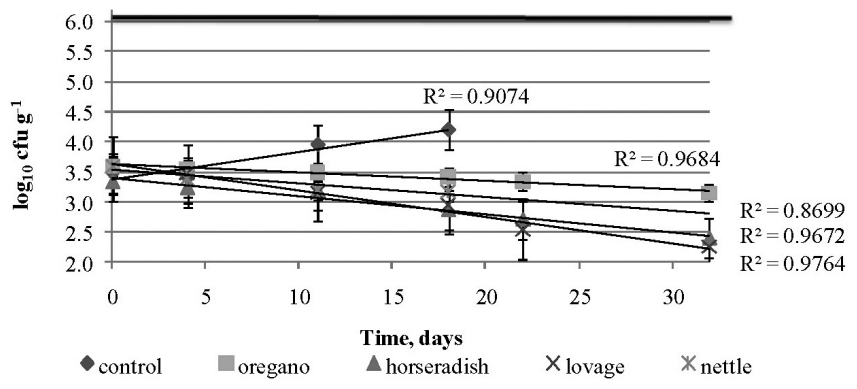

Fig. 4. Total plate count dynamics in control and pork samples with herbal extracts during storage.

the maximum number of microorganisms was accepted in accordance with the Russian sanitary and epidemiological regulatory enactment "Hygienic Requirements for Safety and Nutrition Value of Food Products. Sanitary Rules and Regulations (SanPin) 2.3.2.1078-01" $-5 \times 10^{6} \mathrm{CFU} \mathrm{g}^{-1}$, which is considered a critical limit value when performing microbiological analysis of meat (Anonymous, 2002). The total plate count (Fig. 4) of chilled pork was $3.37 \log _{10} \mathrm{CFU}$ $\mathrm{g}^{-1}$. During the storage period the total plate count increased significantly $(p<0.05)$ in the control sample, reaching 4.2 $\log _{10} \mathrm{CFU} \mathrm{g}$-1 on day 18 , whereas for the pork meat samples with nettle, lovage, oregano, and horseradish extracts it decreased during storage time. The meat samples with nettle extract on day 22 reached $3.2 \log _{10} \mathrm{CFU} \mathrm{g}{ }^{-1}$, but at the end of the experiment on day 32 the meat samples with oregano, horseradish, and lovage extracts reached $3.2 \log _{10} \mathrm{CFUg}^{-1}$, $2.4 \log _{10} \mathrm{CFU} \mathrm{g}{ }^{-1}$, and $2.3 \log _{10} \mathrm{CFU} \mathrm{g}{ }^{-1}$, respectively.

The Enterobacteriaceae are a large family of gram-negative facultative anaerobic bacteria, which includes many patho- 
gens, such as Salmonella, Escherichia coli, etc. Therefore, the counts of these bacteria are among the most important microbiological indicators in the food industry. The Commission Regulation (EC) No 2073/2005 on Microbiological Criteria for Foodstuffs prescribes that the limit of the Escherichia coli count for meat preparations is $500(\mathrm{n}=5, \mathrm{c}=2$; where $\mathrm{n}$ - number of units comprising the sample; $\mathrm{c}$ - number of sample units giving value over $\mathrm{m}$ or between $\mathrm{m}$ and $\mathrm{M} ; \mathrm{m}, \mathrm{M}-$ limit of values) $\mathrm{CFU} \mathrm{g}^{-1}$, which is considered as a critical limit value in this research. The Escherichia coli belong to the Enterobacteriaceae group of bacteria, which encompasses also other bacteria affecting meat quality. This study singles out the activity of this group of bacteria in general. The count of Enterobacteriaceae (Fig. 5) during storage changed significantly $(p=0.041)$. After 18 days of storage, the count of Enterobacteriaceae for the control samples reached $3.4 \log _{10} \mathrm{CFU} \mathrm{g}{ }^{-1}$. For the meat samples with nettle extract the bacteria count was $2.4 \log _{10} \mathrm{CFU} \mathrm{g}^{-1}$ on the $22^{\text {nd }}$ day of storage, and on the last day of the experiment for the samples with oregano, horseradish, and lovage extracts it was $3.1 \log _{10} \mathrm{CFU} \mathrm{g} \mathrm{g}^{-1}, 2.5 \log _{10} \mathrm{CFU} \mathrm{g}{ }^{-1}$, and $2.7 \log _{10} \mathrm{CFU} \mathrm{g}{ }^{-1}$.

Probably, lactic acid bacteria through the intestinal canal can penetrate into muscle tissues during slaughter. The most abundant metabolite produced by lactic acid bacteria (LAB) is lactic acid, which causes a decrease in the $\mathrm{pH}$ of the meat. During storage of meat samples in vacuum packaging,



Fig. 5. Enterobacteriaceae dynamics in control and pork samples with herbal extracts during storage.

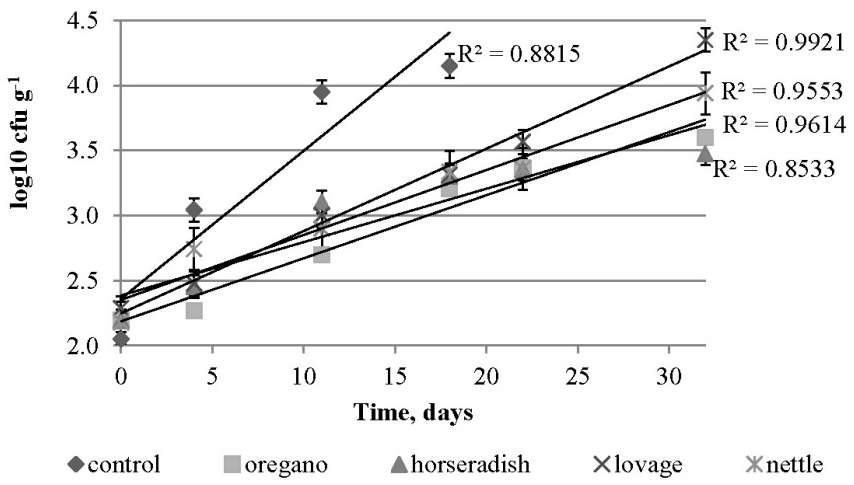

Fig. 6. Lactic acid bacteria dynamics in control and pork samples with herbal extracts during storage.
LAB did not increase significantly $(p=0.891)$. The increase of LAB count in meat samples (Fig. 6) was more rapid in the control sample than in the meat samples with herbal extracts.

On day 18 , the $\mathrm{LAB}$ count for the control samples was 4.1 $\log _{10}$ CFU g ${ }^{-1}$. For meat samples with nettle extract it reached $3.4 \log _{10} \mathrm{CFU} \mathrm{g} \mathrm{g}^{-1}$ on day 22, but for the samples with oregano, horseradish, and lovage extracts $-3.6 \log _{10}$ $\mathrm{CFU} \mathrm{g} \mathrm{g}^{-1}, 3.5 \log _{10} \mathrm{CFU} \mathrm{g}{ }^{-1}$, and $4.3 \log _{10} \mathrm{CFU} \mathrm{g} \mathrm{g}^{-1}$ at the end of the experiment.

\section{DISCUSSION}

Nowadays people are showing a greater interest in foods that contain bioactive or functional componets that provide additional benefits to their health status (Hygreeva et al., 2014). Among foods, meat and meat products occupy a prominent position in the human diet because of their high-quality protein content, essential amino acids and an excellent source of B-group vitamins, minerals and other nutrients (Zhang et al., 2010). Many consumers believe that meat and meat product consumption is unhealthy because of the high animal fat, cholesterol, synthetic antioxidants and antimicrobials content which may be associated with several degenerative diseases. Food technologists and nutritionists have been making great efforts to develop novel meat products with low fat and low sodium content containing natural antioxidants and antimicrobials and enriched with dietary fibre and $\omega-3$ and $\omega-6$ fatty acids (Hygreeva et al., 2014).

During the storage of mature meat, autolysis begins, whereby proteins and fats start to break down. A peptide bond breaks down from the action of cathepsins and peptidases, and fat hydrolysis occurs due to the action of lipase. Due to changes in proteins and also muscle tissue morphological structure, meat juice secretes, and brown surface colour and unpleasant sour taste appears. Such meat is unfit for human consumption (Januškevičienè et al., 2012).

The highest phenolic concentration of herbs was found in oregano and horseradish leaves. Oregano has been reported as a potential dietary source of natural antioxidants for improving human health and stability of food products ( $\mathrm{Su}$ et al., 2007; Dubova et al., 2011; Peńalvo et al., 2016). Also previous studies have shown significant amounts of phenolic compounds in horseradish leaves (Tomsone and Kruma, 2013) and their possibilities to inhibit oxidation of oil (Tomsone and Kruma, 2015). In this study lovage showed significantly lower total phenol Levisticum officinale, whereas in the study performed by Tomsone et al. (2014) significantly higher levels were reported for lovage. Nettle phenolic Levisticum officinale was lower. The presence of several active compounds in stinging nettle has been demonstrated, giving scientific justification to traditional folk uses of the plant. Comparing the total phenol Levisticum officinale of infusions, for oregano the total phenol Levisticum officinale was also previously reported to be 
eight times higher than for nettle (Jiménez-Zamora et al., 2016) which is in accordance with current results.

Plants are persistently a generous source which supply people with valuable bioactive substances. These natural substances from plants, in the forms of extracts, have been obtained from different sources such as fruits, vegetables, herbs, and spices. These plant extracts are prepared from the plant material by using different solvents and extraction methods. These extracts are generally rich in phenols.

Ethanol concentration for extraction of the highest total phenol concentration was $50 \%$. Similar results were obtained by Oreopoulou et al. (2003), who reported an optimum ethanol concentration within the range from $50 \%$ to $60 \%$.

Several researchers reported herbs as rich sources of compounds with antimicrobial activity (Serrano et al., 2011; Giner et al., 2012). For meat products microbial safety is essential and the use of antimicrobials from herbs to improve the quality of meat has been an important field of research during recent years (Zhang et al., 2010; Radha Krishnan et al., 2014). The Latvian oregano samples showed significant antimicrobial activity (Dubova et al., 2011). In the current study oregano showed properties of inhibiting the growth of microorganisms. The antimicrobial activity of nettle was lower compared to lovage and horseradish. Other researchers found water extracts of nettle have a noticeable antimicrobial activity against Gram-positive and -negative bacteria when compared with standard and strong antimicrobial compounds such as miconazole nitrate, amoxicillin-clavulanic acid, ofloxacin, and netilmicin (Gülçin et al., 2004).

Overall, the results demonstrate the effectiveness of the tested herbs for inhibiting microbial growth, thus extending the shelf-life of meat and meat products. The incorporation of spice and herb extracts inhibits major pathogenic organisms such as Salmonella enteritidis, Listeria monocytogenes, and Staphylococcus aureus in different meat products (Hygreeva et al., 2014).

Spices have an antimicrobial ability mainly due to their phenol compounds. The possible mechanisms for antimicrobial effect of phenol compounds include: altering microbial cell permeability; interfering with membrane function including electron transport, nutrient uptake, protein and nucleic acid synthesis, and enzyme activity; and interacting with membrane proteins causing deformation in structure and functionality (Zhang et al., 2010).

Meat is a perfect medium for the development of microorganisms, thus changes happening during meat storage depend not only on the tissue enzymes, but also on the activities of microorganisms. Microbiological deterioration of meat is directly related to the animal's pre-slaughter condition: meat from sick, hungry and tired animals deteriorates quickly (Januškevičiené et al., 2012). During trading, meat and meat products are exposed to microbial contamination, and therefore it is critical to ensure the quality of meat (Silina, 2014).

\section{CONCLUSION}

To obtain the highest total phenolic concentration from dried nettle, lovage, oregano, and horseradish the optimum concentration of ethanol/water for the extracts was $50 \%$ / $50 \%$. Among the studied herbs, the highest total phenolic concentration was found in oregano and horseradish. Changes of meat quality and its sensory properties for chilled pork without extracts packed in vacuum bags appeared on the $18^{\text {th }}$ day of storage. Horseradish, oregano, lovage and nettle extracts preserve pork meat. Taking into account the quality and sensory properties of meat samples with nettle extract, the storage time was prolonged to 22 days and 32 days when horseradish, oregano, and lovage extracts were used. There was a statistically significant difference between the control samples and meat samples with herbal extracts for TPC and counts of Enterobacteriaceae family bacteria.

\section{ACKNOWLEDGEMENTS}

This research was supported by National Research Programme "Agricultural Resources for Sustainable Production of Qualitative and Healthy Foods in Latvia" (AgroBioRes) (2014-2017), project No. 4 "Sustainable use of local agricultural resources for qualitative and healthy food product development" (FOOD).

\section{REFERENCES}

Anonymous (2002). Enactment date of sanitary and epidemiological rules and regulations "Hygienic Requirements for Safety and Nutrition Value of Food Products. Sanitary Rules and Regulations (SanPin) 2.3.2.1078-01" (01.07.2002). Available at:

http://www.gosstandart.info/data/documents/sanpin2.3.2.1078-01.doc

Anonymous (2005). Commision Regulation (EC) No 2073/2005 on Microbiological Criteria for Foodstuffs.

Arhipova I., Bāliņa S. (2006). Statistika ekonomikā. Risinājumi ar SPSS un Microsoft Excel [Economics Statistics. Solutions with SPSS and Microsoft Excel]. Datorzinību centrs, Rīga. 352 lpp. (in Latvian).

Chan E. W. C., Lim Y. Y., Wong S. K., Lim K. K., Tan S. P., Lianto F. S., Yong M. Y. (2009). Effect of different drying methods on the antioxidant properties of leaves and tea of ginger species. Food Chem., 113, 166-172.

Dai J., Mumper R. J. (2010). Plant phenolics: Extraction, analysis and their antioxidant and anticancer properties. Molecules, 15 (10), 7313-7352.

Dawidowicz, A. L., Wianowska, D., Baraniak, B. (2006). The antioxidant properties of alcoholic extracts from Sambucus nigra L. (antioxidant properties of extracts). Lebensmittel-Wissenschaft und Technologic, 39, 308-315.

Devatkal, S. K., Thorat, P., Manjunatha, M. (2014). Effect of vacuum packaging and pomegranate peel extract on quality aspects of ground goat meat and nuggets. J. Food Sci.Technol., 51 (10), 2685-2691.

Dubova, L., Alsina, I., Balins, A., Rungis, D., Kruma, Z., Zukauska, I. (2011). Determination of antibacterial and antiradical activity of Origanum vulgare clones grown in Latvia. Acta Horticult., 925, 291-297.

Giner, M. J., Vegara, S., Funes, L., Martí, N., Saura, D., Micol, V., Valero, M. (2012). Antimicrobial activity of food-compatible plant extracts and 
chitosan against naturally occurring micro-organisms in tomato juice. $J$. Sci. Food Agricult., 92 (9), 1917-1923.

Gülçin, Ż., Küfrevioglu, Ö. Ż., Oktay, M., Büyükokuroglu, M. E. (2004). Antioxidant, antimicrobial, antiulcer and analgesic activities of nettle (Urtica dioica L.). J. Ethnopharmacol., 90 (2), 205-215.

Hayouni, E. A., Chraief, I., Abedrabba, M., Bouix, M., Leveau, J. Y., Mohammed, H., Hamdi M. (2008). Tunisian Salvia officinalis L. and Schinus molle L. essential oils: Their chemical compositions and their preservative effects against Salmonella inoculated in minced beef meat. Int. J. Food Microbiol., 125, 242-251.

Huq, T., Vu, K. D., Riedl, B., Bouchard, J., Lacroix, M. (2015). Synergistic effect of gamma $(\gamma)$-irradiation and microencapsulatedantimicrobials against Listeria monocytogenes on ready-to-eat (RTE) meat. Food Microbiol., 46, 507-514.

Hygreeva, D., Pandey, M. C., Radhakrishna, K. (2014). Potential applications of plant based derivatives as fat replacers, antioxidants and antimicrobials in fresh and processed meat products. Meat Sci., 98, 47-57.

Januškevičienè, G., Zaborskienė, G., Kabašinskienė, A. (2012). Evaluation of Meat Physical, Chemical and Technologica Quality. Kaunas. 121 pp.

Jiménez-Zamora A., Delgado-Andrade C., Rufián-Henares, J. A. (2016). Antioxidant capacity, total phenols and color profile during the storage of selected plants used for infusion. Food Chem., 199, 339-346.

Kanner, J. (1994). Oxidative processes in meat and meat products: Quality implications. Meat Sci., 36, 169-174.

Karakaya, M., Bayrak, E., Ulusoy, K. (2011). Use of natural antioxidants in meat and meat products. J. Food Sci. Eng., 1 (1), 1-10.

Kruma, Z., Straumite, E. (2012). Bioloǵiski aktīvas vielas pārtikas produktos [Biologically Active Compounds in Food Products]. Latvia University of Agriculture, Jelgava. 280 lpp. (in Latvian).

Marino, M., Bersani, C., Comi, G. (2001). Impedance measurements to study the antimicrobial activity of essential oils from Lamiaceae and Compositae. Int. J. Food Microbiol., 67, 187-195.

McCarthy, T. L., Kerry, J. P., Kerry, J. F., Lynch, P. B., Buckley D. J. (2001). Assessment of the antioxidant potential of natural food and plant extracts in fresh and previously frozen pork patties. Meat Sci., 57, 177-184.

Miguel, M. G. (2011). Anthocyanins: Antioxidant and/or anti-inflammatory activities. J. Appl. Pharmaceut. Sci., 1 (6), 7-15.

Milda, E. (2015). Spices and herbs: Natural sources of antioxidants - a mini review. Embuscado J. Funct. Foods, 18 (2), 811-819.

Oreopoulou, V., Tzia, C., Liadakis G. (2003). Extraction of natural antioxidants. In: Tzia, C., Liadakis, G. (eds.). Extraction Optimization in Food Engineering. Marcel Dekker Inc., New York, pp. 329-346.

Papadakis, S. E., Abudal-Malek, S., Kamden, R. E., Yam, K. L. (2000). Versatile and inexpensive techniques for measuring colour of foods. Food Technol., 54 (12), 48-51.

Peńalvo, G. C., Robledo, V. R., Callado, C. S.-C., Santander-Ortega, M. J., Castro-Vịzquez, L., Victoria Lozano, M., Arroyo-Jiménez, M. M. (2016). Improving green enrichment of virgin olive oil by oregano. Effects on antioxidants. Food Chem., 197, 509-515.
Rosenthal, A. J. (1999). Food Texture: Measurement and Perception. Aspen Publication, Gaitherburg, Maryland. 311 pp.

Serrano, C., Matos, O., Teixeira, B., Ramos, C., Neng, N., Nogueira, J., Marques, A. (2011). Antioxidant and antimicrobial activity of Satureja montana L. extracts. J. Sci. Food Agricult., 91 (9), 1554-1560.

Shah, M. A., Bosco, S. J., Mir S. A. (2014). Plant extracts as natural antioxidants in meat and meat products. Meat Sci., 98, 21-33.

Silina, L. (2014). Staltbriežu gaḷas pārstrādes produktu kvalitātes izvērtējums [Quality evaluation of red deer meat processing products]. Dissertation Thesis, Latvia University of Agriculture. Jelgava. 134 lpp. (in Latvian).

Søltoft-Jensen, J., Hansen, F. (2005). New chemical and biochemical hurdles. In: Sun, D. W (Ed.). Emerging Technologies for Food Processing, Food Science and Technology. Elsevier Academic Press, Cambridge, $387-416$.

Stević, T., Berić, T., Šavikin, K., Soković, M., Goševac, D., Dimkić, I., Stanković, S. (2014). Antifungal activity of selected essential oils against fungi isolated from medicinal plant. Ind. Crops Prod., 55, 116-122.

Stratil, P., Klejdus, B., Kubin, V. (2007). Determination of phenolic compounds and their antioxidant activity in fruits and cereals. Talanta, 71 (4), 1741-1751.

Su, L., Yin, J. J., Charles, D., Zhou, K., Moore, J., Yu, L. (2007). Total phenolic contents, chelating capacities, and radical-scavenging properties of black peppercorn, nutmeg, rosehip, cinnamon and oregano leaf. Food Chem., 100 (3), 990-997.

Tanabe, H., Yoshida, M., Tomita N. (2002). Comparison of the antioxidant activities of 22 commonly used culinary herbs and spices on the lipid oxidation of pork meat. Animal Sci. J., 73, 389-393.

Tang, S., Kerry, J. P., Sheehan, D., Buckley, D. J., Morrissey, P. A. (2001). Antioxidative effect of added tea catechins on susceptibility of cooked red meat, poultry and fish patties to lipid oxidation. Food Res. Int., 34, 651-657.

Tomsone, L. (2015). Mārrutku un lupstāju bioloǵiski aktīvo vielu izpēte [Investigation of biological active substances in horseradish and lovage]. Dissertation Thesis, Latvia University of Agriculture, Jelgava (in Latvian).

Tomsone, L., Kruma, Z. (2015). Stability of rapeseed oil with horseradish Armoracia rusticana L. and lovage Levisticum officinale L. extracts under medium temperature accelerated storage conditions. Agron. Res., 13 (4), 1120-1130.

Tomsone, L., Kruma, Z. (2013). Comparison of different solvents for isolation of phenolic compounds from horseradish (Armoracia rusticana L.) leaves. In: Proceedings of the $19^{\text {th }}$ International Scientific Conference “Research for Rural Development”, 15-17 May 2013, Jelgava, Latvia. Vol. 1. pp. 104-110

Tomsone, L., Kruma, Z., Thierry, T., Tian, Ming Z. (2014). Natural antioxidants of horseradish and lovage extracted by accelerated solvent extraction. J. Hygienic Eng. Design, UDC 635.162:542.613]:615.272, pp. 16-24

Viskelis, P., Rubinskiene, M., Jasutiene, I., Sarkinas, A., Daubaras, R., Cesoniene, L. (2009). Anthocyanins, antioxidative, and antimicrobial properties of American cranberry (Vaccinium macrocarpon Ait.) and their press cakes. J. Food Sci., 74 (2), 157-161.

Zhang, W., Xiao, S., Samaraweera, H., Lee, E. J., Ahn D. U. (2010). Improving functional value of meat products. Meat Sci., 86, 15-31.

Received 12.12.2016

Accepted in the final form 15.11.2017 


\section{AUGU EKSTRAKTI ATDZESĒTAS CŪKGALAS KVALITĀTES NODROŠINĀŠANAI UZGLABĀŠANAS LAIKĀ}

Pēdējos gados pieprasījums pēc dabiskiem antioksidantiem, it īpaši augu izcelsmes, ir strauji pieaudzis. Vairums pieejamo gaḷas produktu satur sāli, nitrītus, etiķi vai citus ķīmiskos konservantus, kas nav ieteicami ikdienas lietošanā. Zinātniskie pētījumi liecina, ka augus un ogas, kā arī to ekstraktus, var izmantot kā konservantus, tādējādi iztiekot bez dažādu piedevu pievienošanas. Pievienojot augu ekstraktus gaḷai un gaḷas produktiem, ir novērojamas nozīmīgas mikroorganismu attīstības izmaiņas uzglabāšanas laikā. Latvijā dabā sastopami dažādi ārstniecības augi, piemēram, nātres (Urtica dioica L.), lupstāji (Levisticum officinale L.), raudene (Origanum vulgare) un mārrutki (Armoracia rusticana L.). Šie augi satur bioloğiski aktīvus savienojumus — fenolus, kam piemìt antioksidantu un antimikrobiālas īpašības. Augos esošos fenolus var izmantot kā aizvietotājus sintētiskajiem antioksidantiem, kas kavē lipīdu oksidēšanos un attiecīgi ietekmē produkta krāsas un garšas izmaiņas. Fenoliem ir liela strukturālā dažādība, līdz ar to dažādas ir arī to bioloğiskās funkcijas un fizioloğiskie efekti. Tādēḷ darba mērḳis ir pētīt augu ekstraktu (spirta/ūdens šḳīdumā) pielietojuma iespējas cūkgaḷas kvalitātes nodrošināšanai uzglabāšanas laikā. Pētījumiem tika izvēlēti četri Latvijā augoši augi — raudenes, mārrutki, lupstāji un nātres, kuriem tika noteikts gaistošo savienojumu sastāvs, kā arī noteikta pievienotā spirta škīiduma optimālā koncentrācija, lai iegūtu augu ekstraktu ar augstāko kopējo fenolu daudzumu. Iepriekšējos pētījumos labākos rezultātus uzrādīja ekstrakti no kaltētiem augiem ar spirta 50\% / ūdens 50\% škīiduma koncentrāciju. Augu ekstraktus pievienoja atdzesētai cūkgalaiai, un tika noteikts uzglabāšanas laiks. Iegūtie rezultāti rāda, ka raudeṇu, mārrutku, lupstāju un nātru ekstraktos izturētas cūkgaḷas paraugi uzglabāšanas laikā ilgāk saglabā savas organoleptiskās īpašības salīdzinājumā ar kontroles paraugu (cūkgaḷa bez piedevām). Eksperimentāli noteikts, ka starp paraugiem ar augu ekstraktiem un kontroles paraugu pastāv būtiskas atškirības MAFAM un Enterobacteriaceae dzimtas baktēriju skaita dinamikā, kā arī pH, ūdens aktivitātes un gaḷas sīkstuma rezultātos. 